\title{
Plasticity of seasonal xylem and phloem production of Norway spruce along an elevational gradient
}

\author{
Tobias Walter Miller $^{1}$ (1) $\cdot$ Dominik Florian Stangler ${ }^{1} \cdot$ Elena Larysch $^{1} \cdot$ Thomas Seifert $^{1,2} \cdot$ Heinrich Spiecker $^{1}$. \\ Hans-Peter Kahle ${ }^{1}$
}

Received: 10 January 2020 / Accepted: 26 May 2020 / Published online: 3 June 2020

(c) The Author(s) 2020

\begin{abstract}
Key message Phloem cell production was less influenced by environmental factors than xylem cell production. The moment of maximum number of conducting phloem cells occurred at the end of the growing season.

Abstract The understanding of the seasonality of phloem production, its dependence on climatic factors and potential tradeoffs with xylem cell production is still limited. This study determined key tree-ring phenological events and examined the dynamics of phloem and xylem cell production of Norway Spruce (Picea abies (L.) Karst) by sampling microcores during the growing seasons 2014 and 2015 along an elevational gradient $(450 \mathrm{~m}, 750 \mathrm{~m}, 1250 \mathrm{~m}$ a.s.l.) in south-western Germany. The onset of phloem formation preceded xylem formation at each elevation by approximately 2 weeks, while cessation showed no clear differences between the stands. Maximum rates of xylem and phloem cell production were observed around the summer solstice, independent of elevation. No linear pattern was found in the occurrence of phenological events along the elevational gradient. Phloem formation appeared to be less sensitive to environmental conditions since no difference was found in the number of produced sieve cells between the 2 years of study, whereas the ratio of xylem to phloem cells was significantly smaller in the year 2015 with summer drought. The total number of conducting, non-collapsed phloem cells did not culminate as expected at the time of the potential maximum assimilate production, but at the end of the growing season. Thus, interpretation of phloem formation should not be limited to the function of assimilate transport but should follow a more holistic view of structural-functional relationships of conductive tissues and tree physiological processes.
\end{abstract}

Keywords Picea abies $\cdot$ Phloem $\cdot$ Cambial activity $\cdot$ Xylem $\cdot$ Tree ring phenology

\section{Introduction}

Secondary growth in trees is the result of cambial activity that produces both acropetal conducting xylem cells and basipetal conducting phloem cells (Larcher 2003). As dynamics of secondary growth are under the control of environmental factors (Agusti and Greb 2013), analysis at the cellular level is a proven tool to study their effects on

Communicated by Vospernik.

Tobias Walter Miller

Tobias.Miller@iww.uni-freiburg.de

1 Institute of Forest Science, Chair of Forest Growth, Albert-Ludwigs-University Freiburg, Tennenbacher Str. 4, 79106 Freiburg, Germany

2 Department for Forest and Wood Science, Stellenbosch University, Private Bag X1, 7602 Matieland, South Africa tree growth (Gričar 2012; Deslauriers et al. 2017). Detailed knowledge about the intra-annual dynamics of cambial activity is important for several reasons. On the one hand not only the quantity of formed cells is decisive, but also their timing of formation due to the related processes such as transport and storage (Vichrová et al. 2011; Swidrak et al. 2014). On the other hand, information about the intra-annual dynamics of cambial cell production is relevant to investigate the influence of climate and weather on the physiology, phenology and structure of conducting cells and their alterations as an adaptation to climatic changes (Deslauriers et al. 2017; Lundqvist et al. 2018).

During recent years, studies on the intra-annual dynamics of xylem formation have become quite common (e.g. Moser et al. 2010; Cuny et al. 2014), while comparable studies of phloem are still relatively scarce (e.g. Gričar and Čufar 2008; Prislan et al. 2013). As Čufar et al. (2011) pointed out, apart from pioneer studies in the 1960s and 1970s on the 
seasonal dynamics of phloem formation in several conifers and deciduous trees (e.g. Evert 1963; Alfieri and Evert 1968; Davis and Evert 1968; Tucker and Evert 1969; Davis and Evert 1970; Alfieri and Evert 1973; Alfieri and Kemp 1983), there are only a handful of studies from recent years dealing with the same topic. However, annual phloem formation is crucial for tree survival and the functionality of the entire plant body, since in addition to assimilates, proteins, RNA and electrical wound signals, almost all endogenous plant hormones are transported in the phloem (Oparka 1999; van Bel 2003; Taiz and Zeiger 2006) and except for situations of unfavourable growth conditions sieve cells in conifers are functional mostly only for one to two years (Abbe and Crafts 1939; Holdheide 1951; Evert et al. 2009). Moreover, the function of the xylem is closely related to the phloem (Zimmermann and Brown 1980; Evert et al. 2009; Woodruff 2014).

Under average conditions the cambium of most tree species produces more xylem than phloem cells (Larson 1994; Plomion et al. 2001; Evert et al. 2009). The rate of phloem cell formation is mainly endogenously controlled as it is quite stable throughout the growing season and between the years, while the number of xylem cells is highly influenced by abiotic and biotic environmental factors and thus varies considerably (Alfieri and Evert 1968; Rosner et al. 2001; Gričar and Čufar 2008; Gričar et al. 2009, 2014b, 2015; Gričar 2012; Prislan et al. 2013; Swidrak et al. 2014). Hence, the xylem-phloem ratio is considered to be a good indicator of tree vitality (Gričar et al. 2009, 2014a; Gričar 2012), as reduced tree vitality is characterized by a decreased xylem formation compared to vigorous trees (Fink 1986).

In several coniferous species, the reactivation of the cambium in spring seems to be preceded by the differentiation of partially developed phloem cells originating from the previous year (Alfieri and Evert 1968, 1973; Antonova and Stasova 2006, 2008; Gričar and Čufar 2008; Vichrová et al. 2011). However, it is uncertain whether the subsequent periclinal cell divisions in the cambium are initiated simultaneously on the phloem and xylem side (Rees 1929; Gričar and Čufar 2008; Gričar et al. 2014b), or start first on the phloem side as indicated by heating experiments (Oribe et al. 2001; Gricar et al. 2006; Begum et al. 2010a) and as described for several coniferous species (Alfieri and Evert 1968, 1973; Jyske et al. 2015). In contrast to the reactivation of the cambium in spring, the cessation of cell division in autumn seems to take place simultaneously on the phloem and xylem side of the cambium (Evert 1963; Alfieri and Evert 1968, 1973; Davis and Evert 1968, 1970; Gričar 2010; Gričar et al. 2014b).

In cold environments ambient air temperature seems to play a key role in the onset of cambial activity (Rossi et al. 2008), which was found for high elevations sites (Deslauriers et al. 2008), sites close to the timberline (Rossi et al.
2007) as well as for particular sites in the temperate zone (Prislan et al. 2013; Gričar et al. 2014b). The effect of ambient air temperature on the reactivation of the cambium in spring is corroborated by heating experiments (Oribe et al. 2001; Gricar et al. 2006; Begum et al. 2010b). However, ambient air temperature is effective only in the quiescent phase but not in the antecedent resting stage of the cambium, which follows cessation of cambial activity in autumn (Begum et al. 2010a, 2013). In contrast to the onset, cessation of cambial activity can be affected by water availability (Kahle 2006; Eilmann et al. 2011; Swidrak et al. 2014). The timing of transition from early to late phloem, indicated by the formation of a tangential band of parenchyma cells, seems to be unaffected by temperature (Gričar et al. 2007), although delayed formation at higher altitudes was reported (Gričar and Čufar 2008). Studies investigating the timing of the transition between earlywood and latewood formation are still rather scarce (Cuny et al. 2014; Ziaco and Biondi 2016; Ziaco 2020), and a systematic comparison with the analogous phloem phenophase is still lacking.

It is documented for several tree species that the time at which the rate of xylem cell production is peaking is synchronized with the summer solstice, especially in cold areas (Antonova and Stasova 2006, 2008; Rossi et al. 2006a; Gričar et al. 2007; Jyske et al. 2015). Furthermore, the production of structural woody biomass in the xylem tracheid matrix seems to coincide with the mid-summer maximum of xylem cell production (Cuny et al. 2015). Most studies on conifers as well as deciduous tree species, found that phloem production peaked before xylem production by about three to four weeks (Prislan et al. 2013; Gričar et al. 2014b; Swidrak et al. 2014).

Few researchers have jet addressed the formation of phloem depending on varying climatic factors, and it is unanswered to which extent phloem cell formation is coordinated by endogenous and exogeneous factors (Gričar et al. 2015). Systematic studies along gradients of changing environmental factors, such as elevational transects, which allow the attribution and assessment of the effects of exogenous factors on cell formation more precisely, are needed. With regards to Norway spruce (Picea abies L. Karst), there is currently widespread and growing concern about its vitality in the future. Gričar (2012) and Gričar et al. (2009, 2014a) suggested the ratio of xylem to phloem cells as an indicator of vitality. However, little work has been done on this topic, and comparative studies between periods of high stress levels due to extreme environmental conditions and reference periods are needed.

The present study investigated the phenology of phloem and xylem growth ring formation in mature Picea abies trees along an elevational gradient in the Black Forest (southwestern Germany). The number of phloem and xylem cells were examined and the timing of the different tree-ring 
phenological events was recorded during the years 2014 and 2015 at nine sample trees from three different elevations. The year 2015 was distinguished by a pronounced summer drought. This investigation also aimed at monitoring the intra-annual development of the entire conducting, non-collapsed phloem, including the new cells from the current year as well as non-collapsed phloem cells from previous years. Based on our current knowledge, the following research hypotheses were formulated:

(H1) Onset and maximum of phloem cell formation will precede that of the xylem, but the end of cambial cell production will not show any difference between the formation of the two cell types.

(H2) As in our study region seasonal average air temperature decreases with increasing elevation, a shortening of the growing season along the elevational gradient is assumed due to a later onset and an earlier cessation of cell production. In addition, a shift of the transition from early to late phloem, as well as from earlywood to latewood towards the end of the year is also anticipated with increasing elevation.

(H3) Phloem cells can remain conductive for longer under unfavourable growth conditions; hence, it is expected that with increasing elevation a larger number of sieve cells will overwinter from the end of the growing season.

(H4) As the highest rate of photosynthesis is usually reached at the time of the summer solstice, trees conduct most assimilates at this time. That is why conductive capacity of sieve cells should be maximum during this period. It is therefore hypothesised that the total number of conducting, non-collapsed phloem cells will peak shortly before the summer solstice.

(H5) Phloem cell formation is known to be relatively stable and insensitive to changing environmental conditions. For this reason, no difference in the number of overwintering phloem cells at the end of the growing seasons in 2014 and 2015 is expected.

(H6) As xylem formation is sensitive to environmental conditions causing stress on trees, it is assumed that the relation of xylem to phloem cells is lower in the drought year (2015) than in the non-drought year (2014).

\section{Materials and methods}

\section{Study area}

The study site is part of the long-term dendroecological field monitoring of the Chair of Forest Growth, Albert-LudwigsUniversity Freiburg, and located in the southern Black Forest. The research design consists of three sample sites along an elevational gradient at the Schauinsland mountain, with the lowest elevation at $450 \mathrm{~m}$ a.s.l at Günterstal (LOW; $47.957067^{\circ} \mathrm{N}, 7.868090^{\circ} \mathrm{E}$ ), $750 \mathrm{~m}$ a.s.l. at Heibrain (MED; $47.926254^{\circ} \mathrm{N}, 7.872882^{\circ} \mathrm{E}$ ) and $1,250 \mathrm{~m}$ a.s.l. close to the Schauinsland summit (HIGH; $\left.47.912869^{\circ} \mathrm{N}, 7.904526^{\circ} \mathrm{E}\right)$. The sample sites are located at western (LOW), north-western (MED) and northern aspect (HIGH) and at all sites the soil is characterised as a loamy and gritty, moderately fresh cambisol with a humus layer of mull or mullmoder. The potential natural vegetation is defined as a structured, mixed forest of European beech (Fagus sylvatica) and Silver fir (Abies alba), with small (Luzulo-Fagetum) or large (AbietiFagetum) proportions of fir. At the highest elevation site, the Luzulo-Fagetum with Picea abies is dominating. All stands are mixed-species forest stands with groupwise intermixed Picea abies, Abies alba and Fagus sylvatica, whereas large proportions of Pseudotsuga menziesii are found at the low elevation site as well (Abetz et al. 1993).

\section{Climate}

The study area is located in the temperate zone and characterized by an oceanic climate. Within the study area, the vertical gradient of mean annual air temperature is $-0.5^{\circ} \mathrm{C}$ and of mean annual precipitation $+70 \mathrm{~mm}$ per increase in elevation by $100 \mathrm{~m}$ (Stangler 2016). Table 1 provides baseline climate data of the study area, showing mean annual air temperature, mean total annual precipitation, and values for the growing season (April-Sept) for the period 1981-2010 (Stangler 2016).

To compare the climatic conditions of the years 2014 and 2015 with the long-term baseline climate, meteo data from the meteorological station Emmendingen-Mundingen $\left(48.138^{\circ} \mathrm{N}, 7.835^{\circ} \mathrm{E}, 201 \mathrm{~m}\right.$ a.s.l.) of the German Meteorological Service (DWD), at a distance of about $20 \mathrm{~km}$ from the research plot LOW (Günterstal), were analysed. Based on these data both years were compared, regarding monthly means of air temperature and relative humidity as well as monthly precipitation sums (Fig. 1). Monthly means of available water capacity were simulated with the deterministic forest hydrological model WBS3 (Matzarakis et al. 2000), which was parametrized according to the site conditions at the low elevation site.

Table 1 Baseline climate for the selected forest sites Günterstal (LOW), Heibrain (MED) and Schauinsland (HIGH): average climate data for the period 1981-2010 (Stangler 2016)

\begin{tabular}{llll}
\hline & LOW & MED & HIGH \\
\hline Mean annual air temperature, ${ }^{\circ} \mathrm{C}$ & 8.1 & 6.9 & 4.4 \\
$\begin{array}{l}\text { Mean air temperature (veg. period: April- } \\
\quad\end{array}$ & 14.9 & 13.4 & 10.7 \\
$\quad \begin{array}{l}\text { Sept), }{ }^{\circ} \mathrm{C} \\
\text { Annual precipitation sum, mm }\end{array}$ & 1128 & 1446 & 1683 \\
$\begin{array}{l}\text { Precipitation sum (veg. period: April-Sept), } \\
\text { mm }\end{array}$ & 676 & 840 & 931 \\
\hline
\end{tabular}


Fig. 1 Weather conditions in 2014 and 2015 compared to baseline climate (1981-2010). Displayed are monthly deviation of the mean values from the baseline climate (bold horizontal zero line) for air temperature (a), relative humidity (b), precipitation sum (c) and available water capacity (d), for the years 2014 (green line) and 2015 (red line). Shaded areas represent the 5 th and 95 th percentile of the annual deviations from the 30 years mean value. The calculations are based on data from the meteorological station Emmendingen-Mundingen of the German Weather Service. The monthly available water capacity was modelled with the deterministic forest hydrological model WBS3 (Matzarakis et al. 2000) parametrized according to the site conditions at the low elevation site
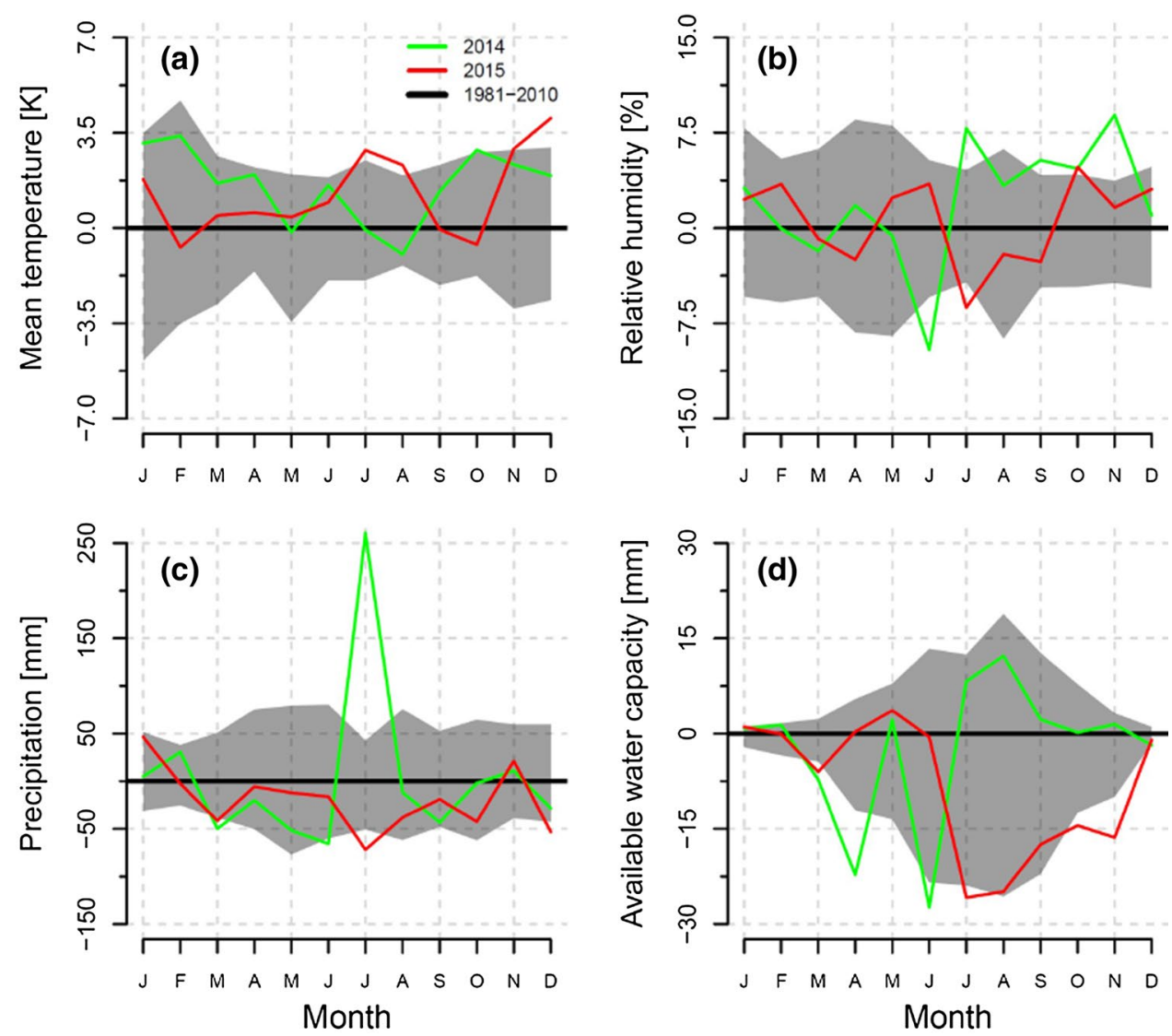

From Fig. 1a-c it can be seen that July and August were particularly dry and warm in 2015 compared to the baseline climate and the year 2014. Due to the above-average rainfall in July 2014, the available water capacity was considerably higher from this month onwards than in 2015, when it was virtually permanently well below average until the end of the year (Fig. 1d). Based on these data, July and August of the year 2015 can be regarded as extraordinarily dry and hot, with growth conditions considerably worse compared to the previous year.

\section{Microcoring, sample preparation and wood anatomical measurements}

At each site three $P$. abies sample trees (nine in total) were selected. They were classified as dominant or co-dominant, with an age of about 60-80 years at the lower elevation sites and about $80-140$ years at the highest plot. The diameter at breast height $(\mathrm{dbh})$ of the sample trees ranged between 50 and $60 \mathrm{~cm}$.

Microcores were collected at weekly intervals from the beginning of April until the end of November in 2014. In the following year, microcore sampling started in mid-April at LOW and MED and at the end of April at HIGH. In 2015 the last microcores were collected at the middle of September at LOW and HIGH and at the beginning of November at MED. A lack of data occurred between mid-May to midJuly at LOW and MED. However, a comparison between both years was possible for the selected response variables described below.

Microcoring was performed with a Trephor tool (Rossi et al. 2006b) at an extraction area which encompassed 1/3 of the steam circumference and which was located at a stem height between $0.7 \mathrm{~m}$ and $1.1 \mathrm{~m}$ above ground. Microcores were sampled in ascending rows within the defined extracting area at the stem surface with a distance of $2.5 \mathrm{~cm}$ in tangential and axial direction and $10.0 \mathrm{~cm}$ between the rows, to avoid disruptive effects by wound reactions. Sampling was conducted perpendicular to the direction of the slope to reduce the effect of compression wood. Immediately after extracting the cores from the stem, they were stored in a 50\% ethanol solution. In order to prevent tissue layers from disintegration, the samples were stored at $5{ }^{\circ} \mathrm{C}$ at the laboratory.

Microcores were dehydrated in a graded ethanol series $(65 \%, 80 \%, 90 \%$ and $100 \%)$, infiltrated in glycolmethacrylate (Technovit 7100, Heraeus Kulzer GmbH, Hanau, Germany) and polymerized after adding an accelerator. In a next step, thin sections of the transversal plane of the embedded microcores of approximately 15-20 $\mu \mathrm{m}$ thickness were cut with a sliding microtome (Gärtner et al. 2014) and stained with 
Cresyl Violet Acetate $(0.16 \%$ in $100 \mathrm{ml}$ distilled water). The stained sections were mounted on glass slides with Canada Balsam in 2014 and with Glycerine in 2015.

For microscopic analysis, a Nikon Eclipse Ni-E upright motorized microscope (Nikon Corporation, Düsseldorf, Germany) with an automatic scanning-table and a colour camera with a resolution of 5 megapixels and 12-bit colour depth (Nikon DS-Fi2) was used to take digital photographs. Images were taken with a $10 \times$ and $20 \times$ objective with a resolution of $0.49 \mu \mathrm{m}$ pixel $^{-1}$ and $0.24 \mu \mathrm{m} \mathrm{pixel}^{-1}$, respectively. Cell counts were performed by using NIS-Elements software (Version 4.20.01, Nikon Corporation, Düsseldorf, Germany, 2014).

In addition to the microcores, an increment core was taken from each of the examination trees after the 2015 growing season. To distinguish earlywood and latewood, Mork's criterion of each cell along five tracheid files was calculated based on wood anatomical measurements using ImageProPlus 7.0 (Media Cybernetics Inc., Rockville, MD, USA) (Denne 1989; Cuny et al. 2014).

\section{Cell counts and definition of stages of development of phloem and xylem cells}

In accordance with Gričar and Čufar (2008), the number of phloem cells was counted along three radial files per sample and averaged. Cells are defined as being in the stage of secondary wall thickening by birefringence of the cell walls under polarized light. Expanding cells-those between the cambium and the wall thickening cells-are usually described as being larger than cambial cells and without secondary cell walls, and were considered to be cells in the stage of cell enlargement (Gričar and Čufar 2008; Swidrak et al. 2014). Since the differentiation between enlarging cells and cambial cells is imprecise, a threshold diameter of $11 \mu \mathrm{m}$ was determined to distinguish between the two cell developmental stages in this study. This value was derived from exploratory measurements of unambiguously determined cells and led to $95 \%$ correctly classified expanding cells.

Phloem cells were assigned as early phloem, late phloem or parenchyma cells, either of the current, or the previous year. Early phloem cells are located between the crushed sieve cells of the previous year and the tangential band of axial parenchyma cells, while late phloem cells are produced after the tangential band of axial parenchyma cells was laid down (Fig. 2) (Alfieri and Evert 1968). Phloem axial parenchyma cells were identified by their dark stained contents in the cell lumina (Gričar et al. 2016).

Xylem cells were counted in accordance with the method described in Stangler (2016), along three radial files per sample and averaged. Here, the border between the cambial

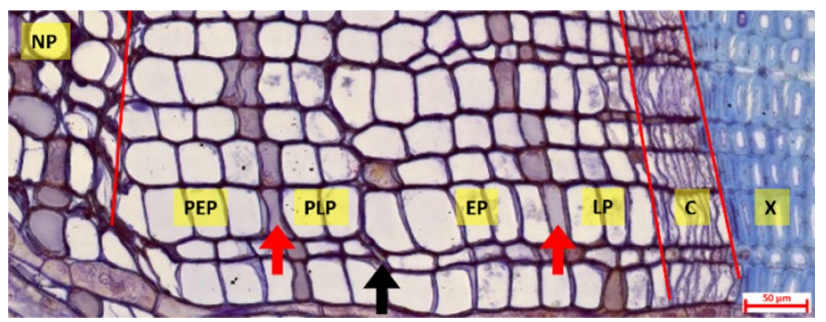

Fig. 2 Typical phloem growth ring consisting of xylem (X), the cambium (C), early phloem (EP) and late phloem (LP) separated by the axial parenchyma band (red arrow). The separation from the previous year is done by the crushed sieve cell (black arrow). From the previous year late phloem (PLP) as well as some early phloem (PEP) cells are preserved, before the nonconducting phloem (NP) follows. The image is taken from the sample of tree 2 at HIGH on 24th of September 2014. Scale bar $50 \mu \mathrm{m}$

zone and cell enlargement cells was defined by the irreversible transition of tracheid radial diameters across the threshold of $14 \mu \mathrm{m}$, which corresponds to twice the radial diameter of an average cambial cell (Vieira et al. 2014; Cuny et al. 2015).

\section{Modelling and statistical methods}

All data analyses and modelling were performed using the $\mathrm{R}$ programming environment ( $\mathrm{R}$ Core Team, 2018, version 3.5.0). Table 2 lists the origins of the data required for hypothesis testing. Points in time extracted from the data were determined as the arithmetic mean of the day of year (DOY) showing the phenological event and the DOY of the previous sampling date. If possible, growth phenology estimates were derived directly from the data. If such empirical information was not available, tree-ring phenological and growth estimates were derived from different models fitted to the data. To assess monotonic patterns of xylem and phloem production in the year 2014, for which a consistent weekly time series of xylogenesis data was available, we fitted a set of deterministic growth functions with subsequent model selection based on the minimum AIC value (Akaike 1998). As candidate models we used two cumulative Weibull functions (for details see Ritz and Streibig (2005)) and a Gompertz function (for details see Duchesne et al. (2012)), which were fitted to the data at the individual tree level. To take account of the high degree of variability of tracheid numbers along the tree circumference, xylem increments were standardised as proposed by Rossi et al. (2003).

The xylem and phloem growth ring phenological phases (1) onset, (2) cessation, (3) duration, (4) time of maximum cell production, and (5) transition from earlywood to latewood were investigated, as well as (6) the total number of conducting phloem cells, (7) the number of overwintering sieve cells, and (8) the number of xylem and phloem cells 
Table 2 Tree-ring phenological events and further data on seasonal xylem and phloem growth dynamics used for hypothesis testing with their origin (derived from the data, from a parametric model or from a GAM)

\begin{tabular}{lll}
\hline & Phloem & Xylem \\
\hline Onset of cell production $\left(t_{\text {on }}\right)$ & Data & Data \\
Cessation of cell production $\left(t_{\text {ce }}\right)$ & Parametric model & Data \\
Duration of cell production $(\Delta t)$ & $t_{\text {off }}-t_{\text {on }}$ & $t_{\text {off }}-t_{\text {on }}$ \\
Maximum rate of cell production $\left(t_{\text {max }}\right)$ & Parametric model & Parametric model \\
Transition earlywood/latewood, early phloem/late phloem $\left(t_{\text {trans }}\right)$ & Data & GAM/parametric model \\
Total number of conducting, non-collapsed phloem cells $(\mathrm{TCP})$ & GAM & - \\
Overwintering sieve cells $($ OSC) & Data & - \\
Cells at the end of the growing season $(\mathrm{CEGS})$ & Data & Data \\
\hline
\end{tabular}

at the end of the growing season. The phenological phases and the assignment to the groups of cells which were derived from the data were defined as follows:

(1) As phloem cells can overwinter in the enlargement stage and thus can be found all year-round, the onset of seasonal phloem cell production was defined by the occurrence of new cells with secondary cell walls. The onset of seasonal xylem cell production was defined by the occurrence of enlarging cells adjacent to the cambium on the xylem side (Rathgeber et al. 2011; Stangler et al. 2016). (2) The cessation of xylem cell production was defined as the time at which no enlarging cells on the xylem side were observed anymore (Rathgeber et al. 2011; Stangler et al. 2016). Due to the above-mentioned continuous presence of phloem cells in the enlargement stage, the end of phloem formation was defined as the state at which the number of modelled cells had reached $95 \%$ of the upper asymptote of the selected deterministic growth function. (3) The duration of both phloem and xylem cell productions were defined as the delta between the onset and cessation of cell production, respectively. (4) The peak of the first derivatives of the deterministic growth functions defined the corresponding time of maximum cell production rate.

(5) The birefringence of secondary cell walls of the axial parenchyma band, indicated the transition between early phloem and late phloem (Alfieri and Evert 1968; Gričar and Čufar 2008). To assess the timing of earlywood to latewood transition, we integrated the information of the xylogenesis data and the raw measurements of the wood anatomical analysis. First, we modeled the final cell number and corresponding value of Mork's criterion at each relative position within the tree-ring using a generalized additive model (GAM). Then, we rescaled the cell number gained in the wood anatomical analysis to the mean value of all total cell numbers of the xylogenesis observations sampled after the end of the xylem cell enlargement. The cell number representing the transition between earlywood and latewood was assessed by the corresponding crossing of the threshold of 1 in Mork's criterion. Finally, the corresponding onset of latewood formation was derived by linking the cellular information of Mork's criterion with the temporal information of the deterministic growth function used for modeling seasonal dynamics of xylem production as described above.

(6) The total number of conducting, non-collapsed phloem cells (TCP) was calculated as the sum of early and late phloem cells of all years in a conducting stage, without taking the axial parenchyma cells in consideration. To predict the DOY when the maximum of the TCP occurred, a GAM was fitted to the weekly counts of each tree.

(7) As overwintering sieve cells (OSC) we counted the sieve elements that did not collapse during the winter and which were still in conductive function before the onset of production of new phloem cells in spring of the following growing season. (8) We also compared the number of cells at the end of the growing season (CEGS) and xylem to phloem ratios between the years 2014 and 2015. As the incomplete time series 2015 did not allow to model the seasonal patterns of phloem production to finally assess the end of phloem production as described above, we chose for each tree the first sample before and after the end of xylem cell production as the common reference point in both years for the comparison of CEGS. At these selected samples, the number of phloem cells were averaged. To assess the corresponding number of xylem cells, we also used the mean value of all total cell numbers of the xylogenesis observations sampled after the end of the xylem cell enlargement.

To compare the DOYs for the different tree-ring phenological response variables $\left(t_{\mathrm{on}}, t_{\mathrm{ce}}, t_{\max }, \Delta t, t_{\text {trans }}\right)$ for xylem and phloem cells along the elevational gradient, linear models (LMs) with interaction terms were applied. For all models, both factors elevation (low, medium or high) and cell type (xylem or phloem) were defined as categorical predictors. Two-way analysis of variance (ANOVA) was conducted to compile tables with $p$ values and $F$ statistics to detect significant effects of cell type and elevations. To examine whether the time at maximum TCP was significantly earlier than the time of the summer solstice, a one sample Wilcoxon 
Signed Rank Test was performed. To compare the number of overwintering sieve cells (OSC), we applied linear mixed effect models (LMEMs) with elevation as fixed effect and individual trees as random effect to account for the repeated measurement structure of our data. To investigate the effect of elevation and calendar year (2014 and 2015) on the number of CEGS and the ratio of xylem to phloem cells (RXP) the LMEMs were modified by including calendar year and the interaction of calendar year and elevation as additional fixed effects. In order to verify the assumptions behind the LMs and LMEMs, QQ-plots and residual plots were visually inspected.

\section{Results}

\section{Phenology of xylem and phloem along an elevational gradient}

One of the aims of this research was to investigate possible differences in the timing of tree-ring phenological events relating to phloem and xylem production at different altitudes. In general, elevation had a significant effect on the results of the LMs for the phenological events onset, cessation and duration of xylem and phloem growth ring formation, as can be seen in Table 3 .

The onset of cell production occurred earlier on the phloem side of the cambium (DOY $103 \pm 14$; mean \pm standard deviation) than on the xylem side (DOY $119 \pm 13$ ) as the ANOVA table depicts pronounced significant differences $(p<0.001)$ between the cell types for the onset of cambial activity. Furthermore, the effect of elevation was significant $(p<0.001)$, indicating differences between the sites. However, no clear linear trend was observed for any of the two cell types along the elevational gradient (see Fig. 3a). The onset of cell production did not differ for either the phloem or the xylem between LOW (phloem: DOY $97 \pm 10$; xylem: DOY $110 \pm 7$ ) and MED (phloem: DOY $94 \pm 8$; xylem DOY $110 \pm 0$ ), while a clear delay was observed at HIGH (phloem: DOY $119 \pm 4$; xylem: DOY $136 \pm 4$ ) in both cell types. Hence, the hypothesis regarding differences between cell types concerning the onset of cambial cell production can be confirmed, but a monotonic linear trend along the elevational gradient was not detected.

In line with the hypothesis $\mathrm{H} 1$, cell production ceased at both sides of the cambium at rather similar times (phloem: DOY $256 \pm 23$; xylem: DOY $246 \pm 15)$ as the ANOVA output shows no significant difference for cell type $(p=0.166)$. Although a significant difference in mean was revealed for the different elevations by the ANOVA $(p=0.014)$, a visual inspection of the data and a comparison of the mean values showed that this was due to the general earlier cessation at the high elevation compared to the medium elevation site (see Fig. 3b). At the two lower sites, phloem production ceased later than at the highest site, but no difference was detected between MED and LOW. The xylem cell production, however, showed a different pattern. The latest cessation of xylem cell production was found at the medium elevation in MED (DOY $264 \pm 7$ ), while cell production ceased at the lowest (DOY $240 \pm 4$ ) and highest elevation (DOY $233 \pm 8$ ) at about the same time. Therefore, the data do not show a linear trend, so that the hypothesis that the cell production ends earlier with increasing altitude is rejected.

An earlier onset and simultaneous end of phloem cell production compared to the xylem should result in a longer period of active growth of the phloem than of the xylem, which was also supported by the data. The growth duration of the phloem ( $153 \pm 32$ days) was significantly longer than the one of the xylem $(127 \pm 25$ days $)$ as indicated by highly significant effects of cell type $(p=0.004)$. Even though the ANOVA table depicts a significant difference between the elevations $(p<0.001)$, a visual inspection of the data and comparison of the means of the phloem data revealed that this was only true for the trees at LOW $(169 \pm 31$ days $)$ and MED (171 \pm 14 days) compared to the trees at HIGH (117 \pm 5 days) (see Fig. $3 \mathrm{c}$ ). The length of the xylem's growing period along the elevation gradient showed a close correlation to the date of cessation of cell production. It lasted the longest at the medium elevation ( $154 \pm 7$ days) but is shortest
Table 3 ANOVA table for the linear regression models with elevation (low, medium or high) and cell type (xylem or phloem) as predictor variables, compiled for all investigated response variables

\begin{tabular}{|c|c|c|c|c|c|c|}
\hline & \multicolumn{2}{|c|}{ Elevation } & \multicolumn{2}{|l|}{ Cell type } & \multicolumn{2}{|c|}{ Interaction } \\
\hline & $F$ & $p$ & $F$ & $p$ & $F$ & $p$ \\
\hline$t_{\text {on }}$ & 29.119 & $<0.001$ & 24.535 & $<0.001$ & 0.131 & 0.879 \\
\hline$t_{c e}$ & 6.199 & 0.014 & 2.1714 & 0.166 & 1.412 & 0.281 \\
\hline$\Delta t$ & 22.559 & $<0.001$ & 13.110 & 0.004 & 1.031 & 0.386 \\
\hline$t_{\max }$ & 1.286 & 0.312 & 0.640 & 0.439 & 0.975 & 0.405 \\
\hline$t_{\text {trans }}$ & 0.577 & 0.576 & 14.063 & 0.003 & 4.376 & $\mathbf{0 . 0 3 7}$ \\
\hline
\end{tabular}

$t_{o n}$ onset of cell production, $t_{c e}$ cessation of cell production, $\Delta t$ duration of cell production, $t_{\max }$ day of maximum rate of cell production, $t_{\text {trans }}$ transition between early and late cells

Significant results $(p<0.05)$ are printed in bold type 
Fig. 3 Effect of elevation on the tree-ring phenological phases of phloem and xylem cell production (a: onset, $\mathbf{b}$ : cessation, $\mathbf{c}$ : duration, $\mathbf{d}$ : maximum rate, $\mathbf{e}$ : transition). Displayed are the day of the year values (DOYs) for each sample tree at the corresponding altitudinal level. Thin, dotted lines connect the mean values of the respective cell types at each altitudinal level (red: phloem, blue: xylem) (a)

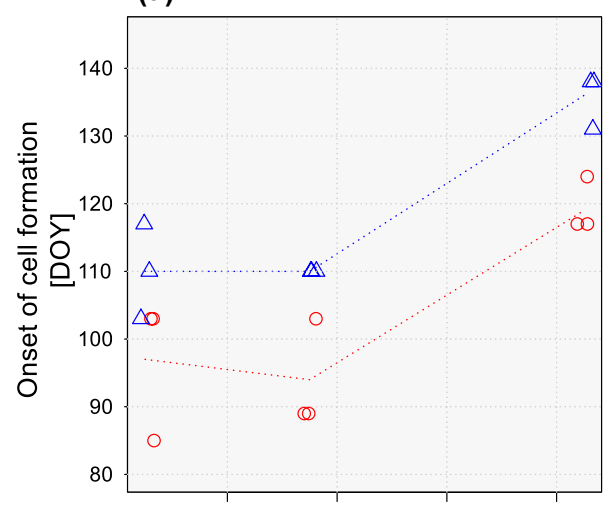

(c)

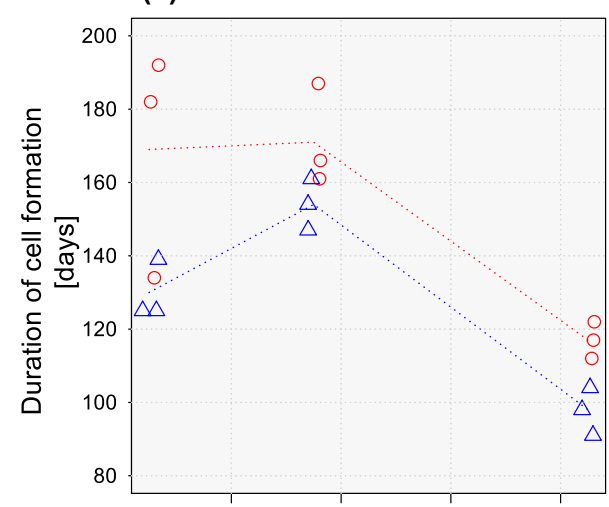

(e)

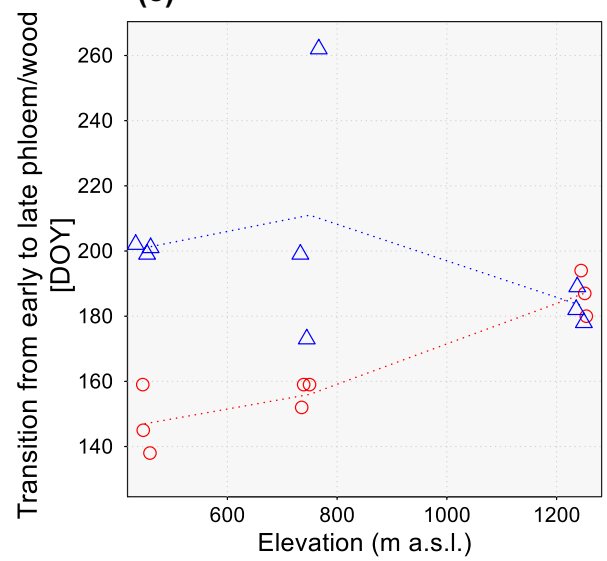

(b)

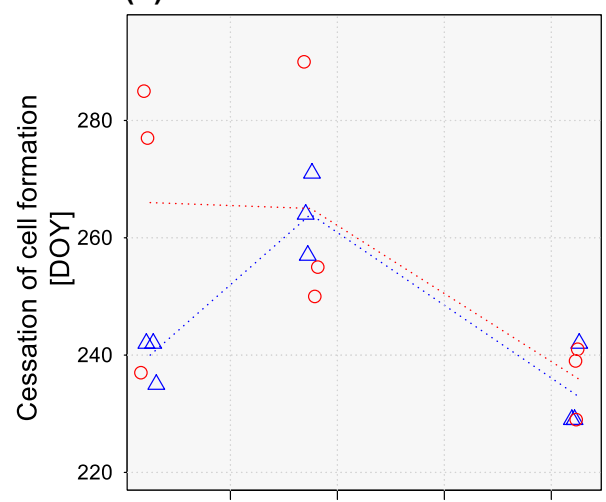

(d)

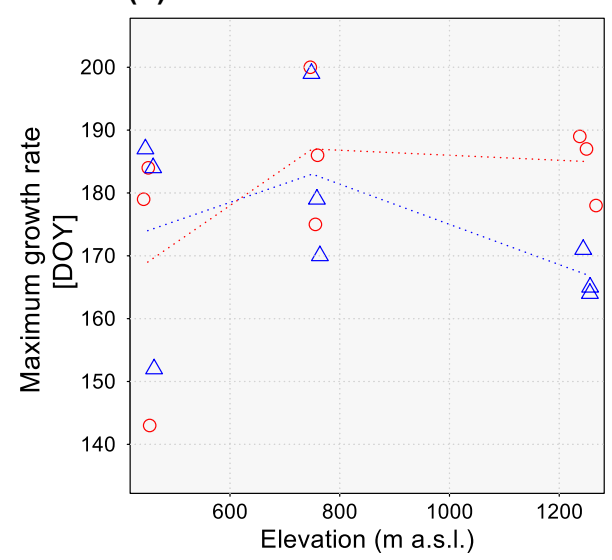

- phloem

$\triangle$ xylem at the highest elevation (98 \pm 7 days). Thus, the hypothesis that the growth duration of both cell types decreases with increasing altitude must be rejected by the present data.

At LOW significantly more phloem cells were produced than at MED, while the xylem shows the opposite pattern (Fig. 4a, c). The day of maximum seasonal phloem cell production showed no significant difference to that of xylem cell production $(p=0.312)$, which is contrary to our initial assumption. The day of maximum cell production occurred around the end of June (phloem: DOY $180 \pm 16$, xylem: DOY $175 \pm 15$ ), i.e. close to the summer solstice (DOY
172) (Fig. 4b, d). Similarly, altitude has no effect on the point in time of maximum cell production $(p=0.439)$ which appeared at about the same time independent of elevation (Fig. 3d). As verified by a two-sided Wilcoxon Signed-Rank test, the point in time of maximum cell production did not differ significantly from the time of the summer solstice neither for the phloem $(p=0.129)$ nor for the xylem $(p=0.767)$.

For the point in time of the transition from earlywood to latewood, as well as from early to late phloem, the effect of cell type and the interaction term both were significant (Table 3). In all cases the transition occurred earlier on 
Fig. 4 Modell predictions of the number of produced phloem (a) and xylem (c) cells in the year 2014, averaged for all sample trees per plot, with the corresponding rates of change $(\mathbf{b}, \mathbf{d})$
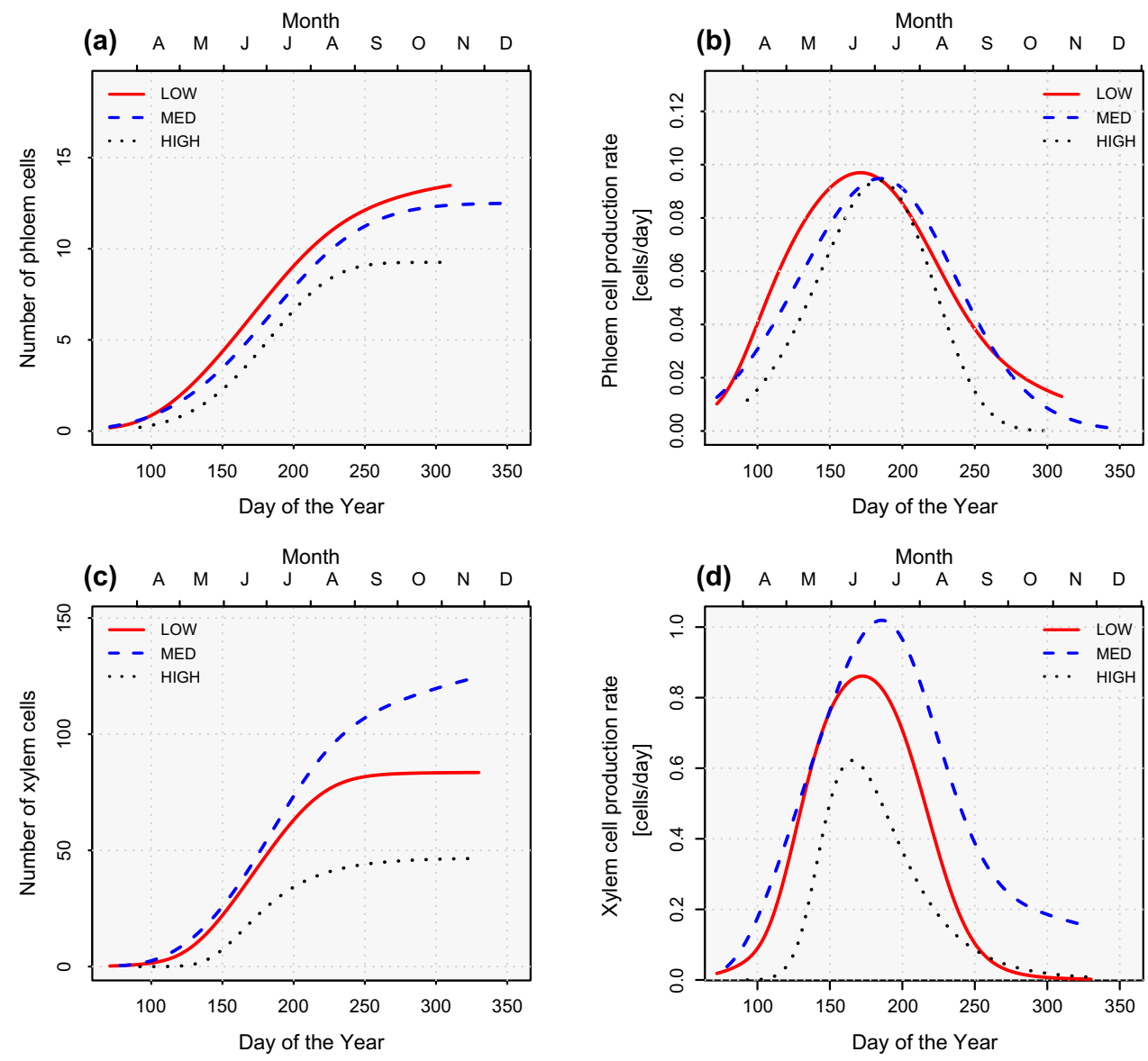

the phloem side (DOY $164 \pm 19$ ) than on the xylem side (DOY 198 \pm 26 ). However, the effect of elevation on the point in time of the transition varied between xylem and phloem as indicated by the significance of the interaction term $(p=0.003)$. The point in time of the transition from early to late phloem occurred later the higher the elevation (Fig. 3e), which is in agreement with our initial hypothesis. This is confirmed by the analysis of the relative timing of the transition from early to late phloem within the growing period (data not shown). The xylem, on the other hand, showed no consistent linear trend along the elevation gradient (Fig. 3e). Between the point in time of transition at LOW (DOY $201 \pm 2$ ) and MED (DOY 211 \pm 45 ) there was a delay of only 10 days, while at HIGH (DOY $183 \pm 6$ ) the transition took place almost one month earlier than at MED. Thus, the point in time of the transition for the xylem did not change consistently with increasing elevation, which means that the hypothesis of a linear trend along the elevational gradient has to be rejected for the xylem.

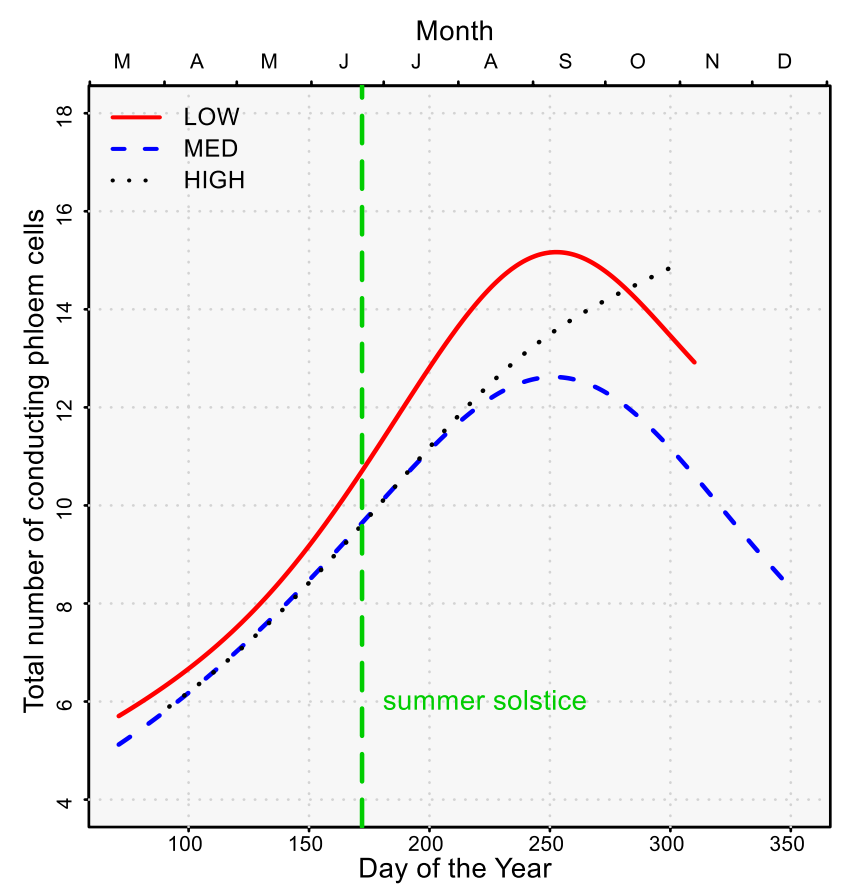

Fig. 5 Total number of conducting phloem cells, averaged for all sample trees per plot. The summer solstice (DOY 172) is marked by a green dashed, vertical line 


\section{Overwintering and maximum number of conducting phloem cells}

Contrary to the previously mentioned assumption, the point in time of maximum number of conducting, non-collapsed phloem cells did not coincide with the summer solstice (DOY 172) but occurred later ( $p=0.997$ ) (Fig. 5). At LOW the peak occurred at DOY $253 \pm 21$, for MED at DOY $262 \pm 22$ and for HIGH as late as DOY $291 \pm 21$. Most conductive phloem cells were observed 13 (at LOW) and 3 days (at MED) before the end of the phloem cell production. The results for HIGH are not reliable, as the number of phloem cells continued to increase despite the end of cell production, which is due to intra-tree variability in the occurrence of multiple conductive annual phloem rings along the stem circumference.

On average across all plots, $5.6 \pm 1.3$ phloem cells overwintered with the smallest number of $4.6 \pm 0.7$ cells at MED and the highest number at HIGH with $6.2 \pm 1.4$ cells (Fig. 6). The ANOVA of the LMEM showed no significant difference in the number of overwintering sieve cells for the different elevations $(p=0.180)$. Hence, the hypothesis that more phloem cells overwinter with increasing elevation must be rejected.

\section{Xylem and phloem growth ring ratio}

On average, $10 \pm 1.8$ phloem cells (mean \pm standard deviation) were formed in 2014 at the end of the growing season and $9.4 \pm 2.8$ in 2015 . Only at HIGH more sieve cells were formed in 2015 than in the previous year (2014: 8.3 \pm 1.5 ;

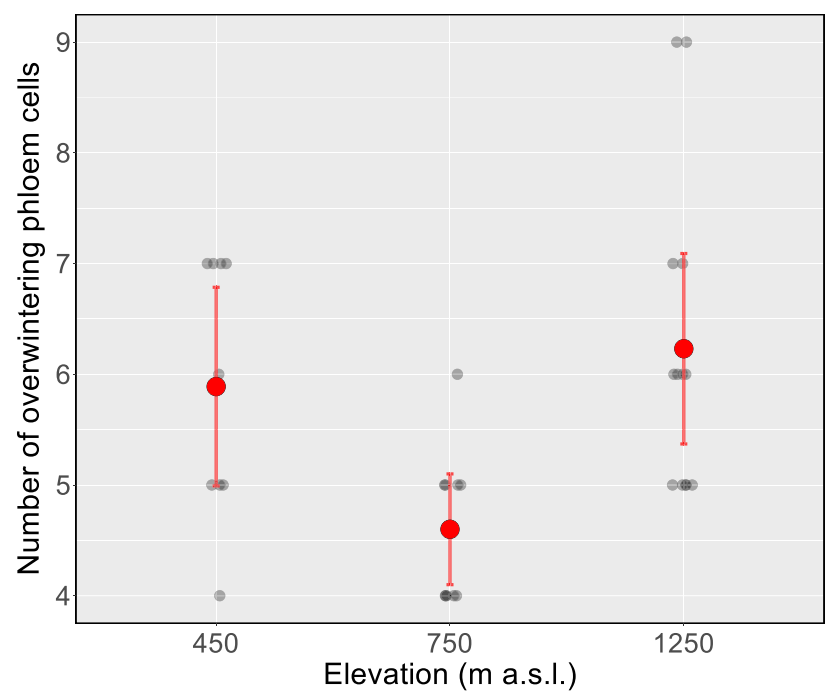

Fig. 6 Mean number of overwintering sieve cells in 2014 for the sample sites according to elevation. Displayed are raw data (grey dots) and mean values (red dots) with error bars indicating standard deviation

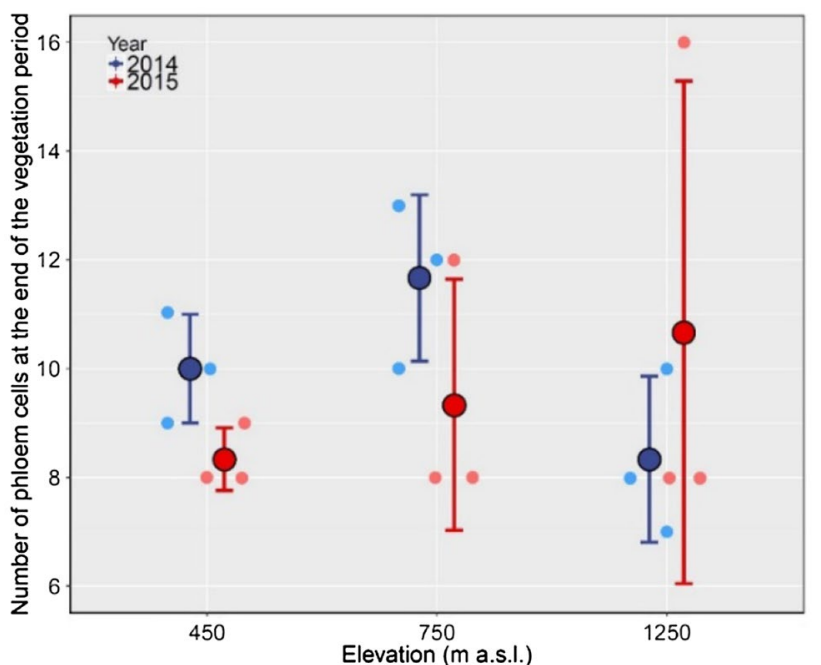

Fig. 7 Mean numbers of phloem cells at the end of the growing season in 2014 and 2015 for the three sites. Displayed are observed numbers (dots) and mean values (circles) with error bars which indicate standard deviation (2014: light blue, 2015: light red)

2015: $10.7 \pm 4.6$ ), which is affected by the extremely large number of sieve cells in one sample tree, causing the standard deviation to be very large (Fig. 7). The difference between 2014 and 2015 was not significant as detected by the ANOVA $(p=0.623)$. Likewise, the effect of elevation and the interaction of both predictors were insignificant (see Table 4), hence, there was no significant difference in the number of phloem cells at the different plots at the end of the growing season (see also Fig. 7).

The cambium produced more xylem than phloem cells with the smallest ratio at HIGH in $2015(4.3 \pm 1.3)$ and the largest ratio at MED in 2014 (10.7 \pm 4.6$)$ (Fig. 8). On average, $84.9 \pm 44.2$ xylem cells were formed in 2014 and $49.4 \pm 12.2$ cells in 2015 , resulting in a mean xylem-phloem ratio of $8.2 \pm 3.3$ in 2014 and $5.4 \pm 1.1$ in 2015 (difference is significant, $p<0.020$ ). Those results are in line with the previous mentioned hypothesis. In contrast, the effect of elevation on the ratio of xylem to phloem cells is not significant.

\section{Discussion}

\section{Xylem and phloem formation phenology}

Prior work has documented effects of environmental factors on the development of the xylem and few studies also included analysis of effects on the phloem. However, these few integrated studies are based on elevational gradients which did not reflect a consistent gradient in precipitation and temperature, due to widely scattered plots at different mountain ranges (e.g. Gričar et al. 2014b). In our study the 
Table 4 ANOVA table for the mixed effects models for the phloem cells at the end of the growing season (CEGS) and the ratio of xylem to phloem cells (RXP), with elevation and calendar year as fixed effects

\begin{tabular}{|c|c|c|c|c|c|c|}
\hline & \multicolumn{2}{|c|}{ Elevation } & \multicolumn{2}{|l|}{ Year } & \multicolumn{2}{|c|}{ Interaction } \\
\hline & $F$ & $p$ & $F$ & $p$ & $F$ & $p$ \\
\hline CEGS & 0.531 & 0.601 & 0.255 & 0.623 & 1.755 & 0.215 \\
\hline RXP & 3.595 & 0.094 & 9.911 & $\mathbf{0 . 0 2 0}$ & 1.450 & 0.306 \\
\hline
\end{tabular}

Significant results $(p<0.05)$ are printed in bold type

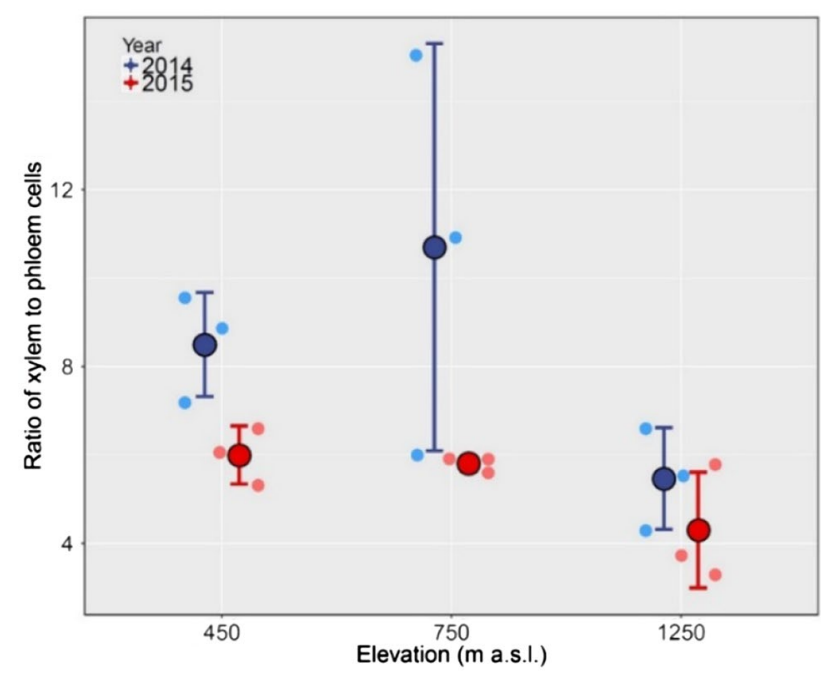

Fig. 8 Ratio of xylem to phloem cells in 2014 and 2015 for the three sites. Displayed are observed values (dots) and mean values (circles) with error bars which indicate standard deviation (2014: light blue, 2015: light red)

data were collected at one mountain range with meteorological conditions consistently changing along the gradient. To the best of our knowledge, this is the first study which systematically investigated seasonal changes in the entire conducting, non-collapsed phloem. Due to the novelty of parts of our analysis and the limited sample size, our findings should be re-examined in future studies with higher number of observations at each elevation site and ideally also replications of the elevational gradients (Moser et al. 2010; Kraus et al. 2016).

Independent of elevation phloem formation preceded xylem formation by approximately 2 weeks, corroborating previous achieved results (Antonova and Stasova 2006, 2008; Gričar and Čufar 2008; Vichrová et al. 2011; Swidrak et al. 2014; Jyske et al. 2015). The earlier start of phloem formation is the result of partially differentiated phloem cells that are formed at the end of the previous growing season and resume differentiation before reactivation of the cambium in spring (Alfieri and Evert 1968, 1973; Antonova and Stasova 2006, 2008; Gričar and Čufar 2008; Vichrová et al. 2011). Sieve cells are destined for the transport of assimilates and other substances from the source tissues to the sink tissues (Nabors and Scheibe 2009). However, as sieve cells are rather short-lived and only a few sieve elements from the preceding year remain conductive, it is essential for the tree in spring to first produce sieve cells in order to be able to transport the assimilates produced by photosynthesis to the meristematic tissues (Evert et al. 2009).

Investigations considering different altitudes consistently found a delay in spring activation of the cambium in higher altitudes (Moser et al. 2010; Prislan et al. 2013; Gričar et al. 2014b). In this study this was only true for the highest altitude at HIGH, while the onset of cell formation at LOW and MED occurred at almost identical points in time. This could be an effect of lower vitality and negative carbon balances of the low elevation trees due to higher probability of water deficits during summer droughts (Kahle 2006). In addition, there is a smaller absolute difference in altitude between the low and medium elevation compared to the medium and high elevation. The observed pattern could indicate a non-linear effect of temperature on the onset of cell formation along the elevational gradient, which is supposed to play a key role in the cambial onset (Deslauriers et al. 2008). Thus, the relevance of temperature could increase exponentially with increasing elevation. Such a non-linear effect of changing temperatures has already been demonstrated for tree growth (D’Arrigo et al. 2008). Although it has been stated that under average environmental conditions tree growth responds less sensitive to climatic factors (Mäkinen et al. 2003), such a consideration is in contradiction to the results of Moser et al. (2010), who found a significant trend for the onset of xylem formation along the elevation gradient.

In line with the results of Gričar (2010) for oak and Gričar et al. (2014b) for spruce, no difference for cessation of cambial activity was found between xylem and phloem cells formation. Nevertheless, this only applies to the stands at MED and HIGH. At LOW, xylem formation ceased almost one month before phloem formation. However, it is important to note that the point in time of the end of phloem cell production does not originate from direct observations but is based on modelled cell production. End of phloem cell production was determined by Jyske et al. (2015) as the time at which $90 \%$ of the total number of phloem cells was reached, 
this could lead to different results than the $95 \%$ limit value chosen in the present study.

Between the study sites, there were differences between phloem and xylem for the cessation of cell production, however, there was no significant correlation with elevation for either cell type. Formation of phloem cells ceased in LOW and MED towards the end of September, at HIGH 1 month earlier in late August. This result is in agreement with Prislan et al. (2013) and Gričar et al. (2014b), who found a delayed end of cell production at lower elevation, but the sample trees at MED again did not follow the trend along the elevational gradient. On the xylem side, cell production at HIGH ceased at the end of August, only one week earlier than in LOW. At the medium elevation in MED, though, cell production continued until mid-September. This result confirms earlier findings, that the point in time of the end of xylem cell production is only loosely related to elevation (Moser et al. 2010).

Heating and cooling experiments have shown that increased temperature can extend the duration of phloem cell production and cooling can initiate earlier cessation of cell production on both sides of the cambium (Gričar et al. 2007; Begum et al. 2016). Likewise, cell production can also be shortened by a lack of water (Swidrak et al. 2014) or extended by an increased supply of water as described in Eilmann et al. (2011). In the present study, the decrease in temperature as well as the increase in precipitation along the elevational gradient is consistent (Table 1). Nonetheless, the trees at MED again showed a pattern that challenges the mentioned results. A possible explanation of this phenomenon could be that the effect of temperature on the cessation of cell production along the elevational gradient follows the shape of an exponential function, as already hypothesized for its onset, and that for the water supply follows the pattern of a square root function. This could explain why xylem cell production in MED takes considerably longer than in LOW and HIGH, since the effect of an extended growing season due to increased precipitation would already occur at a lower elevation and the opposite effect, caused by a lower temperature, would be less conspicuous at such an increase in elevation. These patterns for the impact of the two environmental factors on the cessation of cell production are biologically plausible, since water is the limiting factor at lower altitudes (Mäkinen et al. 2002; Kahle 2006; Gričar et al. 2015), in contrast to temperature at higher altitudes (Mäkinen et al. 2002; Rossi et al. 2008). According to Liebig's "law of the minimum" (Liebig 1840), a change in the limiting factor has a greater effect on plant growth, in this case on the end of the cell production. However, further studies and more data are needed to scrutinise this effect.

Factors other than temperature and precipitation could be involved in the termination of cambial activity, like the need to complete cell maturation of each produced cell before the beginning of winter dormancy (Gricar et al. 2005; Rossi et al. 2008). Time is linked to the photoperiod, which has been highlighted in several studies as being the main driver of growth cessation (Rossi et al. 2006a; Körner and Basler 2010).

Early findings on several coniferous tree species and on beech in temperate regions and on xeric sites suggested that the maximum phloem cell production precedes that of the xylem (Prislan et al. 2013; Gričar et al. 2014b; Swidrak et al. 2014). However, the results of our research were not consistent with those findings, as the timing of maximal growth rates did not differ among xylem and phloem cells. For the xylem, the timing of the maximum growth rate has often been associated with the summer solstice, when daylength peaked (Rossi et al. 2006a; Gričar et al. 2007; Deslauriers et al. 2008), which has already been demonstrated for several conifer tree species (Antonova and Stasova 2006, 2008; Jyske et al. 2015). It was proposed that the cell production rate should decrease after the summer solstice to ensure all tracheids can fully mature before the start of winter (Rossi et al. 2006a). Along the elevational gradient, neither the phloem nor the xylem showed differences in the time of maximum growth rate, which is in line with the results of Gričar et al. (2014b), who did not find statistically significant differences between the sites along the elevational gradient. Due to the small number of data points per altitude in our study, it was not possible to test each plot individually, even if there are indications of differences to the summer solstice, e.g. in MED where the mean value of the maximum phloem production rate is 14 days after the solstice. These results are not unambiguous and should be validated in a larger sample of trees per plot.

To our knowledge, our study is the first comparing the transition timings between early and late phloem of conifers with the corresponding transitions between earlywood and latewood. In previous studies the transition from early to late phloem was usually related to the onset of cambial activity (e.g. Gričar and Čufar 2008; Swidrak et al. 2014; Jyske et al. 2015). In our work, the effect of changing elevation on the phenological event of transition was examined. In the ANOVA, the effect of elevation was significant and a linear trend along the elevational gradient is discernible (Fig. 3e). In the study of Gričar and Čufar (2008), the transition from early to late phloem was observed 1.5 weeks later at the highest stand than at the $850 \mathrm{~m}$ subjacent stand. In the present study, however, a gap of 6 weeks was found between the formation of the axial parenchyma band in LOW and the $800 \mathrm{~m}$ higher site in HIGH. The formation of early phloem is known to be particularly stable (Gričar et al. 2007, 2015; Gričar and Čufar 2008). However, since the transition from early to late phloem did neither occur at a fixed time in relation to the growing period, nor after the same period of time after reactivation of the cambium, an interpretation of the 
results is complicated. The timing of transition depends on the beginning of the cambial activity, the cell production rate and the number of cells in the early phloem. Future work should investigate these factors in more detail in order to find possible explanations and consistent patterns in the temporal dynamics of the axial parenchyma band formation. Contrary to the observation in the phloem, we could visually not detect an effect of elevation on the timing of the transition between earlywood and latewood formation. Across all our investigated sites, the average timing of transition between the two fractions was the 17th of July (DOY 198). This corresponds very closely to the beginning of enlargement of the first latewood cells documented for Norway spruce in the Vosges mountains of France (Cuny et al. 2014). and matches almost exactly the 18th of July, identified for ponderosa pine in two subsequent years growing in the Mojave Desert of Nevada in the USA (Ziaco 2020). Similar as with the timing of the maximum cell production, such similar dates of the earlywood to latewood transition could suggest a considerable influence of the photoperiod that provides an adequate duration of cell maturation for each latewood tracheid (Rossi et al. 2006a; Cuny et al. 2015). This is also supported by previous findings, highlighting the significant influence of day length on cell enlargement duration of latewood cells (Cuny and Rathgeber 2016). It seems, that cell formation does not only depend on the level of climatic factors, but also on the adaptive status of the trees to local conditions (Gričar et al. 2014b, 2015). Furthermore, there are relevant growth factors other than air temperature and precipitation, such as soil type, soil depth and texture or nutrient availability as well as stand conditions that might modify tree growth response (Schmidt et al. 2015); hence, explanations of the timing of phenological events based exclusively on these two factors are strong simplifications. For this reason, such additional factors should be systematically integrated in the upcoming research designs.

\section{Impact of summer drought on radial growth}

Prior work has documented the high priority of phloem formation in the hierarchy of assimilate allocation, due to its crucial importance for tree survival (Evert et al. 2009). For this reason, time invariant, stable phloem formation, relatively independent of changing environmental conditions and controlled primarily by internal factors, is essential for the growth and survival of trees (Alfieri and Evert 1968; Gričar and Čufar 2008; Prislan et al. 2013; Swidrak et al. 2014). In our investigation, we hypothesized that the number of phloem cells would not differ between study years for the reasons given above, although a severe summer drought was recorded in 2015. The presented results support this hypothesis, as no significant differences in the amount of phloem cells between the years could be detected. However, as also the year 2014 was characterized by an early summer drought in June, a longer time series would have been required to generalize these findings. Regarding the different elevations, we could not detect any significant difference, which was expected due to local adaptations, as reported by Gričar et al. (2014b, 2015). Even though we could not show any significant effect of elevation, differences in mean values are discernible, indicating local differences, which might not be significant due to the small sample size and the high standard deviation. Studies with a larger sample size would be needed to verify the hypothesis of local adaption of phloem formation.

Under average conditions the cambium produces more xylem than phloem cells (Larson 1994; Plomion et al. 2001; Evert et al. 2009), whereby the number of xylem cells is subject to greater fluctuations than the number of phloem cells (Rosner et al. 2001; Gričar and Čufar 2008; Gričar et al. 2009; Jyske et al. 2015). That is because the formation of new phloem cells has a higher priority in the carbon allocation hierarchy compared to xylem cells in order to ensure tree survival, since phloem cells are conductive usually for only 1-2 years, unlike xylem cells of conifers which could remain conductive for several years (Gričar et al. 2009). For that reason xylem formation is less endogenously controlled, strongly dependent on varying environmental conditions and decreases sharply under poor growth conditions, resulting in a reduction in the ratio of xylem to phloem cells (Davis and Evert 1968; Gričar et al. 2009). Since the summer of 2015 was extremely dry and warm in comparison to 2014, it was expected that the ratio of xylem to phloem cells would be smaller in 2015. The results of our work were in line with the expectations and showed a significant difference in the ratio of the two cell types between study years. These findings confirm the assumption of a higher fluctuation of cell numbers in the xylem as compared to the phloem in response to environmental stressors such as extreme summer drought.

\section{Overwintering and conducting phloem cells}

It is known from the literature that some mature sieve cells from the previous year can overwinter in a conducting stage (Alfieri and Evert 1968, 1973; Davis and Evert 1970; Antonova and Stasova 2006; Jyske et al. 2015). For Juniperus californica, Alfieri and Kemp (1983) reported that even all of the previous year's phloem cells overwintered in a conducting stage. This corresponds to the observations of Holdheide (1951), according to whom phloem cells can be functional over several years when phloem growth is low, since a sufficient number of conductive cells is necessary for tree survival (Evert et al. 2009). To our knowledge, there are no studies so far that have tested these assumptions for overwintering sieve cells under systematically changing environmental conditions. We could not find a significant 
difference in the number of overwintering phloem cells along the elevational gradient. This finding contradicts the observations of Holdheide (1951) regarding an increasing number of overwintering sieve cells under less favourable growing conditions. However, this observation is vague as the number of conductive phloem rings can vary within a tree, so that the result may vary depending on the location of the sampling along the stem. Nevertheless, the obtained results are encouraging and the study design should be replicated with a larger data set and eventually with larger site amplitude, to test this hypothesis.

Few researchers have addressed the issue of the entire conducting, non-collapsed phloem and the few available reports on the topic are merely an imprecise, qualitative description (e.g. Rees 1929; Alfieri and Evert 1968). Only for Acer negundo there is information stating that the maximum number of conductive sieve elements was observed at the end of the growing season (Tucker and Evert 1969). Also a recent study on Pinus pinea and Pinus halepensis at Mediterranean sites found two maxima for each species in the entire conducting, non-collapsed phloem in spring and autumn, 3 weeks after the number of cambial cells had reached a maximum (Balzano et al. 2020). However, since the maximum cell production rate occurs around the summer solstice (Rossi et al. 2006a; Gričar et al. 2007) and the cell production rate is a good indicator of photosynthetic performance (Waring and Pitman 1985; Waring 1987), this moment was considered to have the highest assimilate flow during the year, consequently demanding a large number of conducting sieve cells. For this reason, we hypothesized that the maximum number of conducting, non-collapsed phloem cells should be synchronized with the highest assimilate flow and thus appear just before the summer solstice. However, this pattern for the maximum number of conducting, noncollapsed phloem cells was not observed. In accordance to the findings of Tucker and Evert (1969), most conducting, non-collapsed phloem cells were observed at the end of the growth period. This theoretically coincides with the timing of the maximum number of cells found in the carbon consuming processes of secondary wall thickening and lignification at the end of August or the beginning of September (Cuny et al. 2013; Stangler 2016). However, Cuny et al. (2015) demonstrated that due to considerably higher rates of secondary wall deposition, the peak of woody biomass production (i.e. total amount of cellulose, hemicellulose and lignin synthesis) usually occurs already in the first half of July.

The hypothesis may suffer from the assumption that assimilates limit the growth of trees and do not consider the other functions of the phloem despite assimilate transport. Only at sites with optimal water and nutrient supply, and the ideal temperature for tissue formation, does a shortage of sugar limit cell production, instead of the rate of meristematic growth (Körner 2012, 2015; Jyske et al. 2015). However, such favourable growth conditions are rarely observed under natural conditions. When cell production rate decreases after culmination, photosynthesis continues at a relatively high level and a shift of assimilates from growth to storage occurs (Körner 2012), as indicated by a decline in the concentration of soluble sugars in the cambium (Deslauriers et al. 2009). On account of the higher priority of substance storage over cell production in terms of assimilate allocation (Waring and Pitman 1985; Waring 1987; Polák et al. 2006), the reserves should already be relatively full by the time cell growth decreases, especially since only the reactivation of the cambium is based on stored carbon, but from the time of xylem formation the carbon is supplied by new photo-assimilates (Deslauriers et al. 2009; Begum et al. 2013; Jyske et al. 2015). Reduced sink activity associated with continuous source activity causes an increase in sugar content in the phloem, resulting in increased viscosity which consequently reduces the flux in the phloem (Turgeon 2010; Nikinmaa et al. 2013; Woodruff 2014). In addition to their size, the number of conducting sieve cells determines the conductive capacity of the phloem (Jyske and Hölttä 2015). When the number of conducting phloem cells increases in proportion to the decrease in sink activity, the increased amount of assimilates is distributed to more sieve cells, viscosity remains constant and phloem transport remains unaffected. Since the phloem transports assimilates as well as phytohormones, signal proteins and mRNA (Oparka 1999; van Bel 2003), which are required for protective reactions against stress caused by pests (van Bel and Gaupels 2004; Walz et al. 2004) or other regulatory processes in the tree, a continuous flow of sap is essential for the survival of the tree. This consideration of the phloem, which goes beyond just assimilate transport, offers a possible ecological explanation for the changing dynamics of the total number of conducting, non-collapsed phloem cells during the growing season.

\section{Conclusion}

Our study demonstrated that the occurrence of tree-ring phenological events along an elevational gradient cannot easily be predicted with linear functions. Tree growth at the two lower altitudes initiated earlier and ceased later than at the highest altitude, but there was little difference between the two lower sites. The results suggest that there is an interactive effect between environmental factors and elevation on the phenology of trees due to different growth limiting factors along the gradient, which makes forecasting difficult. In addition, it was shown that the number of phloem cells in the year 2014 did not differ significantly from the number in the drought year 2015. In contrast, the ratio of xylem to phloem 
cells was lower in 2015. Consequently, phloem formation appeared to be more endogenously controlled than xylem formation and to be less sensitive to climatic variability.

All conducting phloem cells were investigated in this study and unexpected results were obtained as the maximum number of phloem cells in conductive stage did not seem to coincide with the potential timing of maximum photosynthate production. This finding indicates that the phloem formation process is not only relevant to provide sufficient pathways for assimilate transport to the meristems, but also to maintain a certain transport rate necessary for regulatory processes in a tree. These results provide compelling evidence for the influence of climate on cell formation and suggest to broaden the perspective in order to further close the existing knowledge gaps on cell formation processes in the phloem.

Author contribution statement TWM wrote the manuscript with support from DFS, EL, HPK, HS and TS. The study was conceptualized by HS, HPK and DFS. Field work was done by DFS. Microcore analysis was conducted by DFS, EL and TWM. Final data analysis was performed by TWM and DFS with advice from HPK.

Acknowledgements Open Access funding provided by Projekt DEAL. This work was partially supported by the German Research Foundation with Grants SP-437/17 and by the German Federal Ministry of Food and Agriculture and the German Federal Ministry for the Environment, Nature Conservation and Nuclear Safety with Grants: 22W-K-4-148. The authors thank the technical staff of the Chair of Forest Growth and Chair of Forest Botany for supporting the preparation process and the anonymous reviewers of the manuscript for their helpful comments.

\section{Compliance with ethical standards}

Conflict of interest The authors declare that they have no conflict of interest.

Open Access This article is licensed under a Creative Commons Attribution 4.0 International License, which permits use, sharing, adaptation, distribution and reproduction in any medium or format, as long as you give appropriate credit to the original author(s) and the source, provide a link to the Creative Commons licence, and indicate if changes were made. The images or other third party material in this article are included in the article's Creative Commons licence, unless indicated otherwise in a credit line to the material. If material is not included in the article's Creative Commons licence and your intended use is not permitted by statutory regulation or exceeds the permitted use, you will need to obtain permission directly from the copyright holder. To view a copy of this licence, visit http://creativecommons.org/licenses/by/4.0/.

\section{References}

Abbe LB, Crafts AS (1939) Phloem of white pine and other coniferous species. Bot Gaz 100:695-722. https://doi.org/10.1086/334826
Agusti J, Greb T (2013) Going with the wind-Adaptive dynamics of plant secondary meristems. Mech Dev 130:34-44. https://doi. org/10.1016/j.mod.2012.05.011

Akaike H (1998) Information theory and an extension of the maximum likelihood principle. In: Parzen E, Tanabe K, Kitagawa G (eds) Selected papers of Hirotugu Akaike. Springer, New York, pp 199-213

Alfieri FJ, Evert RF (1968) Seasonal development of the secondary phloem in Pinus. Am J Bot 55:518. https://doi.org/10.2307/24405 83

Alfieri FJ, Evert RF (1973) Structure and seasonal development of the secondary phloem in the Pinaceae. Bot Gaz 134:17-25. https:// doi.org/10.1086/336674

Alfieri FJ, Kemp RI (1983) The seasonal cycle of phloem development in Juniperus californica. Am J Bot 70:891. https://doi. org/10.2307/2442941

Antonova GF, Stasova VV (2006) Seasonal development of phloem in Scots pine stems. Russ J Dev Biol 37:306-320. https://doi. org/10.1134/S1062360406050043

Antonova GF, Stasova VV (2008) Seasonal development of phloem in Siberian larch stems. Russ J Dev Biol 39:207-218. https://doi. org/10.1134/S1062360408040024

Balzano A, Micco V de, Čufar K, Luis M de, Gričar J (2020) Intraseasonal trends in phloem traits in Pinus spp. from drought-prone environments. IAWA J. 1-17. https://doi.org/10.1163/2294193200002112

Begum S, Nakaba S, Oribe Y, Kubo T, Funada R (2010a) Cambial sensitivity to rising temperatures by natural condition and artificial heating from late winter to early spring in the evergreen conifer Cryptomeria japonica. Trees 24:43-52. https://doi.org/10.1007/ s00468-009-0377-1

Begum S, Nakaba S, Oribe Y, Kubo T, Funada R (2010b) Changes in the localization and levels of starch and lipids in cambium and phloem during cambial reactivation by artificial heating of main stems of Cryptomeria japonica trees. Ann Bot 106:885-895. https ://doi.org/10.1093/aob/mcq185

Begum S, Nakaba S, Yamagishi Y, Oribe Y, Funada R (2013) Regulation of cambial activity in relation to environmental conditions: understanding the role of temperature in wood formation of trees. Physiol Plant 147:46-54. https://doi.org/10.111 1/j.1399-3054.2012.01663.x

Begum S, Kudo K, Matsuoka Y, Nakaba S, Yamagishi Y, Nabeshima E, Rahman MH, Nugroho WD, Oribe Y, Jin H-O, Funada R (2016) Localized cooling of stems induces latewood formation and cambial dormancy during seasons of active cambium in conifers. Ann Bot 117:465-477. https://doi.org/10.1093/aob/mcv181

Čufar K, Cherubini M, Gričar J, Prislan P, Spina S, Romagnoli M (2011) Xylem and phloem formation in chestnut (Castanea sativa Mill.) during the 2008 growing season. Dendrochronologia 29:127-134. https://doi.org/10.1016/j.dendro.2011.01.006

Cuny HE, Rathgeber CBK (2016) Xylogenesis: coniferous trees of temperate forests are listening to the climate tale during the growing season but only remember the last words! Plant Physiol 171:306317. https://doi.org/10.1104/pp.16.00037

Cuny HE, Rathgeber CBK, Kiessé TS, Hartmann FP, Barbeito I, Fournier M (2013) Generalized additive models reveal the intrinsic complexity of wood formation dynamics. J Exp Bot 64:19831994. https://doi.org/10.1093/jxb/ert057

Cuny HE, Rathgeber CBK, Frank D, Fonti P, Fournier M (2014) Kinetics of tracheid development explain conifer tree-ring structure. New Phytol 203:1231-1241. https://doi.org/10.1111/nph.12871

Cuny HE, Rathgeber CBK, Frank D, Fonti P, Mäkinen H, Prislan P, Rossi S, del Castillo EM, Campelo F, Vavrčík H, Camarero JJ, Bryukhanova MV, Jyske T, Gričar J, Gryc V, de Luis M, Vieira J, Čufar K, Kirdyanov AV, Oberhuber W, Treml V, Huang J-G, Li X, Swidrak I, Deslauriers A, Liang E, Nöjd P, Gruber A, Nabais 
C, Morin H, Krause C, King G, Fournier M (2015) Woody biomass production lags stem-girth increase by over one month in coniferous forests. Nat Plants 1:15160. https://doi.org/10.1038/ nplants.2015.160

D'Arrigo R, Wilson R, Liepert B, Cherubini P (2008) On the 'Divergence Problem' in Northern Forests: a review of the tree-ring evidence and possible causes. Global Planet Change 60:289-305. https://doi.org/10.1016/j.gloplacha.2007.03.004

Davis JD, Evert RF (1968) Seasonal development of the secondary phloem in Populus tremuloides. Bot Gaz 129:1-8. https://doi. org/10.1086/336406

Davis JD, Evert RF (1970) Seasonal cycle of phloem development in woody vines. Bot Gaz 131:128-138. https://doi. org/10.1086/336523

Denne MP (1989) Definition of latewood according to Mork (1928). IAWA J 10:59-62. https://doi.org/10.1163/22941932-90001112

Deslauriers A, Rossi S, Anfodillo T, Saracino A (2008) Cambial phenology, wood formation and temperature thresholds in two contrasting years at high altitude in southern Italy. Tree Physiol 28:863-871. https://doi.org/10.1093/treephys/28.6.863

Deslauriers A, Giovannelli A, Rossi S, Castro G, Fragnelli G, Traversi L (2009) Intra-annual cambial activity and carbon availability in stem of poplar. Tree Physiol 29:1223-1235. https://doi. org/10.1093/treephys/tpp061

Deslauriers A, Fonti P, Rossi S, Rathgeber CBK, Gričar J (2017) Ecophysiology and plasticity of wood and phloem formation. In: Amoroso MM, Daniels LD, Baker PJ, Camarero JJ (eds) Dendroecology: Tree-ring analyses applied to ecological studies, vol 231. Springer Nature, Switzerland, pp 13-33

Duchesne L, Houle D, D’Orangeville L (2012) Influence of climate on seasonal patterns of stem increment of balsam fir in a boreal forest of Québec, Canada. Agric For Meteorol 162-163:108114. https://doi.org/10.1016/j.agrformet.2012.04.016

Eilmann B, Zweifel R, Buchmann N, Graf Pannatier E, Rigling A (2011) Drought alters timing, quantity, and quality of wood formation in Scots pine. J Exp Bot 62:2763-2771. https://doi. org/10.1093/jxb/erq443

Evert RF (1963) The cambium and seasonal development of the phloem in Pyrus malus. Am J Bot 50:149. https://doi. org/10.2307/2439848

Evert RF, Eichhorn SE, Langenfeld-Heyser R (2009) Esaus Pflanzenanatomie: Meristeme, Zellen und Gewebe der Pflanzen - ihre Struktur, Funktion und Entwicklung. De Gruyter, Berlin

Fink S (1986) Microscopical investigations on wood formation and function in diseased trees. IAWA J 7:351-355. https://doi. org/10.1163/22941932-90001005

Gärtner H, Lucchinetti S, Schweingruber FH (2014) New perspectives for wood anatomical analysis in dendrosciences: The GSL1-microtome. Dendrochronologia 32:47-51. https://doi. org/10.1016/j.dendro.2013.07.002

Gricar J, Cufar K, Oven P, Schmitt U (2005) Differentiation of terminal latewood tracheids in silver fir trees during autumn. Ann Bot 95:959-965. https://doi.org/10.1093/aob/mci112

Gricar J, Zupancic M, Cufar K, Koch G, Schmitt U, Oven P (2006) Effect of local heating and cooling on cambial activity and cell differentiation in the stem of Norway spruce (Picea abies). Ann Bot 97:943-951. https://doi.org/10.1093/aob/mc1050

Gričar J, Zupančič M, Čufar K, Oven P (2007) Regular cambial activity and xylem and phloem formation in locally heated and cooled stem portions of Norway spruce. Wood Sci Technol 41:463-475. https://doi.org/10.1007/s00226-006-0109-2

Gričar J, Čufar K (2008) Seasonal dynamics of phloem and xylem formation in silver fir and Norway spruce as affected by drought. Russ J Plant Physiol 55:538-543. https://doi.org/10.1134/S1021 44370804016X
Gričar J (2010) Xylem and phloem formation in sessile oak from Slovenia in 2007. Wood Res 55:15-22

Gričar J (2012) Cambial cell production and structure of xylem and phloem as an indicator of tree vitality: a review. https://www. intechopen.com/books/sustainable-forest-management-curre ntresearch/. Accessed 12 Oct 2018

Gričar J, Krže L, Čufar K (2009) Number of cells in xylem, phloem and dormant cambium in silver fir (Abies alba), in trees of different vitality. IAWA J 30:121-133. https://doi.org/10.1163/22941 932-90000208

Gričar J, Jagodic Š, Šefc B, Trajković J, Eler K (2014a) Can the structure of dormant cambium and the widths of phloem and xylem increments be used as indicators for tree vitality? Eur J Forest Res 133:551-562. https://doi.org/10.1007/s1034 2-014-0784-8

Gričar J, Prislan P, Gryc V, Vavrčík H, de Luis M, Cufar K (2014b) Plastic and locally adapted phenology in cambial seasonality and production of xylem and phloem cells in Picea abies from temperate environments. Tree Physiol 34:869-881. https://doi. org/10.1093/treephys/tpu026

Gričar J, Prislan P, de Luis M, Gryc V, Hacurová J, Vavrčík H, Čufar K (2015) Plasticity in variation of xylem and phloem cell characteristics of Norway spruce under different local conditions. Front Plant Sci 6:730. https://doi.org/10.3389/fpls.2015.00730

Gričar J, Novak K, de Luis M, Čufar K, del Castillo EM, Longares LA, Prislan $P$ (2016) Lack of annual periodicity in cambial production of phloem in trees from mediterranean areas. IAWA J 37:349-364. https://doi.org/10.1163/22941932-20160138

Holdheide W (1951) Anatomie mitteleuropäischer Gehölzrinden (mit mikrophotographischem Atlas). In: Freund H (ed) Handbuch der Mikroskopie in der Technik, 5th edn. Unschau Verlag, Frankfurtam-Main, pp 193-367

Jyske T, Hölttä T (2015) Comparison of phloem and xylem hydraulic architecture in Picea abies stems. New Phytol 205:102-115. https ://doi.org/10.1111/nph.12973

Jyske TM, Suuronen J-P, Pranovich AV, Laakso T, Watanabe U, Kuroda K, Abe H (2015) Seasonal variation in formation, structure, and chemical properties of phloem in Picea abies as studied by novel microtechniques. Planta 242:613-629. https://doi. org/10.1007/s00425-015-2347-8

Kahle H-P (2006) Impact of the drought in 2003 on intra- and interannual stem radial growth of beech and spruce along an altitudinal gradient in the Black Forest, Germany. TRACE 4:152-164

Körner C (2012) Was steuert das Pflanzenwachstum? Biol unserer Zeit 42:238-243. https://doi.org/10.1002/biuz.201210484

Körner C (2015) Paradigm shift in plant growth control. Curr Opin Plant Biol 25:107-114. https://doi.org/10.1016/j.pbi.2015.05.003

Körner C, Basler D (2010) Plant science. Phenology under global warming. Science 327:1461-1462. https://doi.org/10.1126/scien ce. 1186473

Kraus C, Zang C, Menzel A (2016) Elevational response in leaf and xylem phenology reveals different prolongation of growing period of common beech and Norway spruce under warming conditions in the Bavarian Alps. Eur J Forest Res 135:1011-1023. https:// doi.org/10.1007/s10342-016-0990-7

Larcher W (2003) Physiological plant ecology: Ecophysiology and stress physiology of functional groups, 4th edn. Springer, Berlin

Larson PR (1994) The vascular cambium: development and structure. Springer series in wood science. Springer, Berlin

Liebig J (1840) Organic chemistry in its applications to agriculture and physiology. Taylor and Walton, London

Lundqvist S-O, Seifert S, Grahn T, Olsson L, García-Gil MR, Karlsson B, Seifert T (2018) Age and weather effects on between and within ring variations of number, width and coarseness of tracheids and radial growth of young Norway spruce. Eur J Forest Res 137:719-743. https://doi.org/10.1007/s10342-018-1136-x 
Mäkinen H, Nöjd P, Kahle H-P, Neumann U, Tveite B, Mielikäinen K, Röhle H, Spiecker H (2002) Radial growth variation of Norway spruce (Picea abies (L.) Karst.) across latitudinal and altitudinal gradients in central and northern Europe. For Ecol Manage 171:243-259. https://doi.org/10.1016/S0378-1127(01)00786-1

Mäkinen H, Nöjd P, Kahle H-P, Neumann U, Tveite B, Mileikainen K, Röhle H, Spiecker H (2003) Large-scale climatic variability and radial increment variation of Picea abies (L.) Karst. in central and northern Europe. Trees 17:173-184

Matzarakis A, Mayer H, Schindler D, Fritsch J (2000) Simulation des Wasserhaushaltes eines Buchenwaldes mit dem forstlichen Wasserhaushaltsmodell WBS3. Bericht des Meteorologischen Instituts der Universität Freiburg 5:137-146

Moser L, Fonti P, Büntgen U, Esper J, Luterbacher J, Franzen J, Frank D (2010) Timing and duration of European larch growing season along altitudinal gradients in the Swiss Alps. Tree Physiol 30:225-233. https://doi.org/10.1093/treephys/tpp108

Nabors MW, Scheibe R (2009) Botanik. Biologie. Pearson Studium, München

Nikinmaa E, Hölttä T, Hari P, Kolari P, Mäkelä A, Sevanto S, Vesala T (2013) Assimilate transport in phloem sets conditions for leaf gas exchange. Plant Cell Environ 36:655-669. https://doi.org/10.1111/ pce. 12004

Oparka KJ (1999) Sieve elements and companion cells-traffic control centers of the phloem. Plant Cell 11:739-750. https://doi. org/10.1105/tpc.11.4.739

Oribe Y, Funada R, Shibagaki M, Kubo T (2001) Cambial reactivation in locally heated stems of the evergreen conifer Abies sachalinensis (Schmidt) Masters. Planta 212:684-691. https://doi. org/10.1007/s004250000430

Plomion C, Leprovost G, Stokes A (2001) Wood formation in trees. Plant Physiol 127:1513-1523

Polák T, Rock BN, Campbell PE, Soukupová J, Solcová B, Zvára K, Albrechtová J (2006) Shoot growth processes, assessed by bud development types, reflect Norway spruce vitality and sink prioritization. For Ecol Manage 225:337-348. https://doi. org/10.1016/j.foreco.2006.01.027

Prislan P, Gričar J, de Luis M, Smith KT, Čufar K (2013) Phenological variation in xylem and phloem formation in Fagus sylvatica from two contrasting sites. Agric For Meteorol 180:142-151. https:// doi.org/10.1016/j.agrformet.2013.06.001

Rathgeber CBK, Longuetaud F, Mothe F, Cuny H, Le Moguédec G (2011) Phenology of wood formation: Data processing, analysis and visualisation using R (package CAVIAR). Dendrochronologia 29:139-149. https://doi.org/10.1016/j.dendro.2011.01.004

Rees LW (1929) Growth studies in forest trees-Picea rubra Link. J Forest 27:384-404

Ritz C, Streibig JC (2005) Bioassay analysis using R. J Stat Softw 12:1-22

Rosner S, Baier P, Kikuta SB (2001) Osmotic potential of Norway spruce [Picea abies (L.) Karst.] secondary phloem in relation to anatomy. Trees 15:472-482. https://doi.org/10.1007/s0046 8-001-0131-9

Rossi S, Deslauriers A, Morin H (2003) Application of the Gompertz equation for the study of xylem cell development. Dendrochronologia 21:33-39. https://doi.org/10.1078/1125-7865-00034

Rossi S, Deslauriers A, Anfodillo T, Morin H, Saracino A, Motta R, Borghetti M (2006a) Conifers in cold environments synchronize maximum growth rate of tree-ring formation with day length. New Phytol 170:301-310. https://doi.org/10.111 1/j.1469-8137.2006.01660.x

Rossi S, Menardi R, Anfodillo T (2006b) Trephor: a new tool for sampling microcores from tree stems. IAWA J 27:89-97. https://doi. org/10.1163/22941932-90000139

Rossi S, Deslauriers A, Anfodillo T, Carraro V (2007) Evidence of threshold temperatures for xylogenesis in conifers at high altitudes. Oecologia 152:1-12. https://doi.org/10.1007/s0044 2-006-0625-7

Rossi S, Deslauriers A, Griçar J, Seo J-W, Rathgeber CBK, Anfodillo T, Morin H, Levanic T, Oven P, Jalkanen R (2008) Critical temperatures for xylogenesis in conifers of cold climates. Glob Ecol Biogeogr 17:696-707. https://doi.org/10.111 1/j.1466-8238.2008.00417.x

Schmidt W, Stüber V, Ullrich T, Paar U, Evers J, Dammann K, Hövelmann T, Schmidt M (2015) Synopse der Hauptmerkmale der forstlichen Standortskartierungsverfahren der Nordwestdeutschen Bundesländer. Universitätsdrucke, vol 12. Univ.-Verl. Göttingen; Niedersächsische Staats-und Universitätsbibliothek, Göttingen

Stangler DF (2016) Seasonal wood formation dynamics and tree-ring structure of selected tree species in response to climate and forest management. Dissertation, Albert-Ludwigs-Universität

Stangler DF, Mann M, Kahle H-P, Rosskopf E, Fink S, Spiecker H (2016) Spatiotemporal alignment of radial tracheid diameter profiles of submontane Norway spruce. Dendrochronologia 37:3345. https://doi.org/10.1016/j.dendro.2015.12.001

Swidrak I, Gruber A, Oberhuber W (2014) Xylem and phloem phenology in co-occurring conifers exposed to drought. Trees (Berl West) 28:1161-1171. https://doi.org/10.1007/s00468-014-1026-x

Taiz L, Zeiger E (2006) Plant physiology, 4th edn. Sinauer Associates, Sunderland, Mass

Tucker CM, Evert RF (1969) Seasonal development of the secondary phloem in acer negundo. Am J Bot 56:275-284. https://doi. org/10.1002/j.1537-2197.1969.tb07534.x

Turgeon R (2010) The puzzle of phloem pressure. Plant Physiol 154:578-581. https://doi.org/10.1104/pp.110.161679

van Bel AJE (2003) The phloem, a miracle of ingenuity. Plant Cell Environ 26:125-149. https://doi.org/10.1046/j.1365-3040.2003.00963.x

van Bel AJE, Gaupels F (2004) Pathogen-induced resistance and alarm signals in the phloem. Mol Plant Pathol 5:495-504. https://doi.org /10.1111/J.1364-3703.2004.00243.X

Vichrová G, Vavrčík H, Gryc V, Menšík L (2011) Preliminary study on phloemogenesis in Norway spruce: influence of age and selected environmental factors. J For Sci 57:226-232. https://doi. org/10.17221/1836-JFS

Vieira J, Rossi S, Campelo F, Nabais C (2014) Are neighboring trees in tune? Wood formation in Pinus pinaster. Eur J Forest Res 133:4150. https://doi.org/10.1007/s10342-013-0734-X

Walz C, Giavalisco P, Schad M, Juenger M, Klose J, Kehr J (2004) Proteomics of curcurbit phloem exudate reveals a network of defence proteins. Phytochemistry 65:1795-1804. https://doi.org/10.1016/j. phytochem.2004.04.006

Waring RH (1987) Characteristics of trees predisposed to die. Bioscience 37:569-574. https://doi.org/10.2307/1310667

Waring RH, Pitman GB (1985) Modifying lodgepole pine stands to change susceptibility to mountain pine beetle attack. Ecology 66:889-897. https://doi.org/10.2307/1940551

Woodruff DR (2014) The impacts of water stress on phloem transport in Douglas-fir trees. Tree Physiol 34:5-14. https://doi. org/10.1093/treephys/tpt106

Ziaco E (2020) A phenology-based approach to the analysis of conifers intra-annual xylem anatomy in water-limited environments. Dendrochronologia 59:125662. https://doi.org/10.1016/j.dendr o.2019.125662

Ziaco E, Biondi F (2016) Tree growth, cambial phenology, and wood anatomy of limber pine at a Great Basin (USA) mountain observatory. Trees 30:1507-1521. https://doi.org/10.1007/s0046 8-016-1384-7

Zimmermann MH, Brown CL (1980) Trees: Structure and function. Springer, Berlin (4. print)

Publisher's Note Springer Nature remains neutral with regard to jurisdictional claims in published maps and institutional affiliations. 